\section{MUSIC AND POLITICS AFTER THE HOLOCAUST: MENUHIN'S BERLIN CONCERTS OF 1947 AND THEIR AFTERMATH}

\author{
Tina Frühauf \\ RILM/Columbia University \\ TFruhauf@gc.cuny.edu
}

\section{MÚSICA Y POLÍTICA TRAS EL HOLOCAUSTO: LOS CONCIERTOS DE MENUHIN EN EL BERLÍN DE 1947 Y SUS CONSECUENCIAS}

\begin{abstract}
RESUMEN: Entre el 27 de septiembre y el 3 de octubre del 1947, Yehudi Menuhin ofreció seis conciertos en Berlín, dos de ellos con Wilhelm Furtwängler, quien acababa de ser declarado inocente por los tribunales de "desnazificación" en Austria y Alemania. Debido a que el público era alemán y a la participación de Furtwängler, estos conciertos provocaron un fuerte escándalo entre la comunidad judía y la población desplazada de los campos en Alemania, así como entre las comunidades judías en el extranjero. Mi investigación se centra, primero, en el contexto histórico de estos conciertos y, concretamente, la posición de Menuhin y Furtwängler hacia el uno al otro, así como sus respectivos papeles en la Alemania de la postguerra. Posteriormente ofrezco una relación de los acontecimientos de septiembre y octubre de 1947 a través de la mirada de Abraham S. Hyman, asesor legal en Alemania de los Consejeros Americanos sobre Asuntos Judios (American Advisors on Jewish Affairs). Además, investigo el papel de Yehudi Menuhin y sus biógrafos, en cuanto revelan la complejidad de estos acontecimientos. Finalmente, analizo la recepción de los conciertos a fin de entender las razones que causaron el impacto de ese escándalo. En conclusión, propongo que la organización y objetivos de estos conciertos fueron deficientes porque la política jugó un papel importante en un tiempo en que el pueblo judio estaba sufriendo un duro trauma debido a las consecuencias del Holocausto.
\end{abstract}

PALABRAS CLAVE: Posterior a la Segunda Guerra Mundial; Alemania; personas desplazadas; comunidad judia; Yehudi Menuhin; Wilhelm Furtwängler.

\section{INTRODUCTION}

Beginning in 1942, Yehudi Menuhin gave over five hundred concerts during his wartime tours for American and British soldiers, the Red Cross, the Russian War Relief, and other relief organizations. Germany, naturally, was not on his list. Earlier, with Hitler's rise to power, Menuhin had adamantly refused to play in Germany. And even the repeated invitations by grand maestro Wilhelm Furtwängler in August

\begin{abstract}
Between September 27 and October 3, 1947, Yehudi Menuhin gave six performances in Berlin, two of them together with Wilhelm Furtwängler, who had just been cleared by the denazification tribunals in Austria and Germany. Because of the German audience and the Furtwängler collaboration, these concerts led to a scandal in the Jewish community and the Displaced Persons camp in Germany as well as Jewish communities abroad. I turn first to the historical background of these performances, specifically the position of Menuhin and Furtwängler toward each other and their roles in postwar Germany. I will then chronicle the events of September and October 1947 through the lenses of Abraham S. Hyman, legal consultant to the American Advisers on Jewish Affairs in Germany, and Yehudi Menuhin and his biographers, to reveal the complexity of the events. Lastly, I will scrutinize the reception of the concerts to shed light on the reasons for and impact of the scandal. I argue that these concerts were mishandled in their organization and aims, in that politics played too large a role in the events during a time when the Jewish people suffered severe trauma in the aftermath of the Holocaust.
\end{abstract}

KEY WORDS: Post-World War II era; Germany; displaced persons; jewish community; Yehudi Menuhin; Wilhelm Furtwängler.

and September of 1933 to perform with the Berlin Philharmonic Orchestra could not convince the Menuhin family'. These opportunities must have been difficult to turn down for a young violinist in his late teens and it was also difficult for Furtwängler to accept the decision. Indeed, the correspondence between the Menuhins and Furtwängler ended all but amicably, closing with the conductor's emphatic threat: "it is your fault if things are going to the dogs in Germany musically"2. 
Only after the war, in July of 1945, did Menuhin return to Germany, the first visit since his 1929 Berlin debut. During his ten-day trip, he gave two concerts on July 27 , for the recently liberated inmates of the concentration camp Bergen-Belsen in Lower Saxony in northwestern Germany, and a few days later in the Displaced Persons (henceforth DPs) camp at Bardowiek, near Lüneburg. He became the first foreigner to play for Germans in the British zone over the airwaves with the NDWR (now Norddeutscher Rundfunk, NDR) Symphony Orchestra ${ }^{3}$. His performance with Benjamin Britten on July 27 is well documented as is his short tour of Bergen-Belsen, which temporarily became the home of thousands of DPs, refusing to be repatriated to their country of origin, but having few alternatives for emigration until the foundation of the State of Israel and the easing of U.S. visa restrictions in 1948 (Hyman, 1993, 253; Burton, $2000,250-253)^{4}$. Fully realizing the atrocities that had taken place in the former concentration camp, he stated: "I shall not forget that afternoon as long as I live" (Menuhin, 1997, 185).

During his visit to Bergen-Belsen, Menuhin supposedly heard many positive statements about Furtwängler and reported these in interviews with newspapers in the United States (Magidoff, 1955, 270-271). A New York Times article, dated December 5, 1945, quotes Menuhin's surprising first statement on Furtwängler after their 1933 discord: "If there is one musician who deserves to be reinstated... it is Furtwaengler. In all the time he directed in Berlin, he refused to give the Nazi salute at concerts, as was expected of other conductors. And it is well known that he held on to the Jewish members of his orchestra as long as he possibly could. He never allowed himself to be used as a propaganda vehicle in occupied countries. He did not accompany the Berlin orchestra on their [propaganda] tours. When you are a citizen of a country, as he was, his

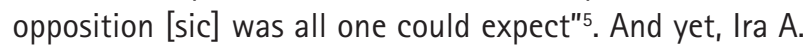
Hirschmann, founder and president of the New Friends of Music, attacked Yehudi for his defense of Furtwängler, saying that he was "horror-stricken" at Menuhin for attempting to "whitewash" the Nazis' official musical director of the Third Reich. "At the very moment when the employers of Mr. Furtwängler are facing international trial for mass butchery, that anyone should attempt to give a clear bill of health to one of their conspirators seems incredible" (Magidoff, 1955, 271) ${ }^{6}$.
In an interview with Sam H. Shirakawa in 1989, Menuhin looked back at the series of events, still defending his decision to support Furtwängler:

I received calls from various Jews -I've forgotten their names, though Ira Hirschmann was certainly one of them- who applied strong pressure on me to dissociate from Furtwängler ${ }^{7}$. Although they didn't say it in so many words, their meaning was clear: if I persisted in backing Furtwängler, I would never play with any of the major orchestras and certainly never again with any of the people who were against Furtwängler. Of course, I did play with the major orchestras again and frequently, but it was a time of hysterical emotions. But I'll tell you one thing, Sam, I would do exactly the same thing if I had the chance to do it over again.... Of all the great conductors I played with, only Furtwängler made one look into the music to search for a truth within it. He was grateful to me for what I did, but he never articulated it in words. The only time Furtwängler said anything remotely hostile about the Allies was when he could not rehearse with me at the time he wanted because of some military bureaucratic procedure. He just sighed and said "So this is what Germany has come to" (Shirakawa, 1992, 354).

What is striking about Menuhin's statement is his argumentation and wording. He defended his decision as a musician reasoning that Furtwängler is simply the best conductor to work with; but he also argued on political grounds claiming that Furtwängler was innocent. Somewhat unsympathetic, he explained the controversy with the zeitgeist as "a time of hysterical emotions", thus minimizing the trauma the concentration camp atrocities had caused not only its immediate survivors, but also the Jewish community at large, as cultural trauma. It somehow appears as if Menuhin's motif to support Furtwängler was rooted in artistic interests. Perhaps Menuhin was concerned that after their unfortunate encounter in 1933, another opportunity to perform with the great conductor would not offer itself easily, especially without standing by Furtwängler during a time when he faced severe accusations. The reception of Menuhin's 1945 defense was a foreboding of possibly more severe responses, if he continued to support Furtwängler.

The two artists finally met for the first time in early January 1946 at the Hôtel Trois Couronnes in Vevey, close to Clarens in Switzerland, where Furtwängler had stayed 
most of the time after he left Germany in February 1945 (Schönzeler, 1990, 109) ${ }^{8}$. But Menuhin's highly anticipated collaboration with Furtwängler had to wait two more years. Because of the conductor's opaque position during the Third Reich ${ }^{9}$, he was still suspended from performing in Germany, with the exception of the Russian Zone ${ }^{10}$. The Russians especially promoted music, and under the writer and lyricist Johannes Robert Becher, who became a member of the Party Executive Committee after returning from exile, they wanted to make the Soviet Zone a refuge for artists (MacDonogh, 2007, 215). Such promotion and support, of course, was not mere altruism, but most likely politically motivated, leaving aside the highly propagandistic reasons for Soviet artistic support -namely, a retort to the Western allies and a means of legitimizing the Soviet Union as a more cultured, civilized alternative. Thus in early 1946 the Soviets offered Furtwängler the post of Artistic Director of the East German State Opera, but the conductor, not yet fully rehabilitated, declined.

On March 9, 1946, the denazification tribunal in Austria, chaired by the head of the Austrian State Theater Administration Hans Perntner and theater director Egon Hibert, cleared Furtwängler. The next day he flew to Berlin on a Soviet military aircraft and held a press conference. But General John McClure of the American Information Control Division, who generally believed in Furtwängler's innocence, against the wishes of most of the German music-loving public, and of the Soviets, the French, and even his own music officers, had to insist that Furtwängler be excluded until his case had been properly investigated by the Berlin Denazification Commission for Artists, a body approved by all four Powers ${ }^{11}$. Thus McClure scheduled the first hearing for Furtwängler's denazification tribunal for December 11, 1946; it was chaired by Alex Vogel, who followed the Communist Party line ${ }^{12}$. The second tribunal took place on December 17, 1946, with witnesses in the conductor's defense, among them stage director Boleslav Barlog, Clemens Herzberg (Max Reinhardt's former manager), and Rudolf Vedder, the concert agent and former vice president of the Reich Music Chamber.

The Spruchkammer charged Furtwängler on the following allegations: his (involuntary) appointment as a Prussian State Councillor (Goebbels appointed him to this post after he refused to join the Nazi party), his support of Nazism by conducting in Germany, his two performances at Nazi party functions, and his allegedly anti-Semitic remark against Italian conductor Victor de Sabata. Furtwängler was acquitted at this trial as the testimony of Jewish colleagues and other witnesses was overwhelmingly in his favor, but no judgment was rendered until the end of April 1947 when he was officially cleared (MacDonogh, 2007, 354-355) ${ }^{13}$.

Although Furtwängler was denazified, his opaque stance during the Third Reich and the subsequent complications of his trial, never let him be fully rehabilitated in the public eye or even in some scholarly literature, and he remained somewhat controversial. Indeed, the Furtwängler debate continued in two main camps: those who assumed Furtwängler's innocence based on his support of some Jewish colleagues and the fact that before 1933 and after 1945 he performed works by Jewish composers (such as Bernhard Sekles's orchestral prelude Dybuk of 1928) ${ }^{14}$, and those who were convinced of the conductor's guilt based on the Spruchkammer allegations ${ }^{15}$.

Although Furtwängler made his more or less triumphant return to Berlin on May 25, 1947, in a concert with the Berlin Philharmonic Orchestra, the denazification process had taken its toll. Furtwängler seemed cautious if not wary in regards to his involvement in Jewish matters. In a letter to Walter Legge, an influential British classical record producer, dated July 3, 1947, he wrote: "The only thing that I personally am afraid of is that my willingness to conduct for the Jewish Charity, which corresponds completely with my whole personal attitude, will simply be branded as sheer opportunism, taking advantage of the occasion. That must be avoided at all costs. I do not want to link any specific political attitude with it, but rather to show that art is above politics. I will always be prepared to offer my artistic skills -for humanitarian reasons- either for the Winter Aid Concert in Germany at present or for the Jewish Charity Concert in London" (Sanders, 1998, 132) While Furtwängler's hesitation seems awkward at first, a further letter to Legge, dated July 8, 1947, confirms the conductor's sincere interested in supporting Jewish causes. In February and March 1948 he conducted the London Philharmonic Orchestra in several charity concerts.

On August 13, 1947, Menuhin and Furtwängler finally gave their very first performance together, Johannes Brahms's Violin Concerto, in Salzburg with the Vienna Philharmonic 
Orchestra. The day after the performance Menuhin arrived in Munich and was contacted by Special Services Officer Samuel Lewis Gaber with an invitation to play for the Jewish DPs in one of the nearby camps. Menuhin's response is unknown ${ }^{16}$. However, Menuhin gave a concert at the Congress Hall of the German Museum in Munich under Joseph Strobl. The concert was fully sold out with Germans, Americans, and DPs in the audience ${ }^{17}$. This was followed by a concert again with Furtwängler at the Lucerne Festival on August 30 with the Beethoven Violin Concerto on the program. On August, 28 and 29, the record producers of His Master's Voice (HMV) also scheduled two recording sessions with the two musicians for the Beethoven Violin Concerto.

A month later, Menuhin and Furtwängler performed together for the first time on German soil and with this stirred a controversy that extended to the DP camps in Berlin and the local Jewish community. Indeed, this affair reached as far as Palestine and the United States. Little did Menuhin, Furtwängler, or for that matter anyone else, know that his concerts would become a highly political issue between different Jewish factions. Newspapers and literature commented on the event as well, however, without taking into consideration the full picture of events and all parties involved.

This article will shed light on the controversy that arose after Menuhin gave a concert for the DPs in Berlin on October 1. In a larger framework I will address how the concerts and the events surrounding them offer insight into postwar musical life and the reconstitution of the Jewish community.

\section{The Performances}

Shortly after the war, the Office of Military Government of the United States (OMGUS) in Germany decided to sponsor a series of charity concerts, with Robert Murphy, then a member of the Office of Military Government, being the driving force behind the invitation to Menuhin. Menuhin's friend, William Dubensy, was also involved with negotiating the visit to show that a new chapter in Germany's history had begun and that the occupation was entering a new phase (Monod, 2005, 165). In the end, Military Governor General Lucius Clay only agreed to Menuhin's visit when Washington ordered a change in the policy, stating that it was unlawful for U.S. citizens to perform before local audiences without governmental authorization (Monod, 2005, 213). In 1946, Menuhin performed for the first time after the war "as a Jew who might keep alive German guilt and repentance, and as a musician offering something to live for" (Menuhin, 1997, 234). Evidently, the dialectics of art and politics that Furtwängler wanted to support dissolved in Menuhin's postwar performances. Moreover, the performances show how music and politics were intrinsically linked in postwar Germany through the notions of trauma, identity, but also opportunism.

In 1946, Menuhin had performed with the Berlin Philharmonic Orchestra under the baton of Sergiu Celibidache who in February 1946 became the orchestra's conductor until Furtwängler's rehabilitation. As these first concerts had not been well received, OMGUS was adamant about not including Furtwängler in forthcoming performances to avoid further complications and failures (see Thacker, 2007, 103). Menuhin did not share this apprehension, and in April 1947 the New York Times announced that he would give the first three of a series of concerts by U.S. artists in Occupied Germany under the baton of Wilhelm Furtwängle ${ }^{18}$. Details on how the inclusion of Furtwängler came to be remain unknown. At the time, speculations arose whether Yehudi Menuhin had made Furtwängler's appearance a condition of his acceptance of an invitation to inaugurate the series ${ }^{19}$. Certainly Menuhin's star power and a higher order from Washington must have played a role. But Harrison Kerr, a well known contemporary composer and chief of the Department of the Army's Music and Arts, Reorientation Branch, War Department, denied that Menuhin's appearance and Furtwängler's clearance were somehow connected ${ }^{20}$.

After his arrival in Berlin on September 27, Menuhin gave a total of six performances ${ }^{21}$ during five days that also included reorientation meetings with German music critics and cultural commentators (Burton, 2000, 282) ${ }^{22}$. The first concert took place on September 28, 1947, at the original 1,920 -seat auditorium of Titania Palast in the south of Berlin. As the Philharmonie was completely destroyed, a number of venues served as temporary homes, one of them being the Titania. The Berlin Philharmonic Orchestra under 
Furtwängler played the Overture of Felix Mendelssohn's $A$ Midsummer Night's Dream, ${ }^{23}$ Beethoven's Symphony No. 7, and with Menuhin as the featured soloist, Beethoven's Violin Concerto. A live-recording was made as well. As the concert benefited British and American victims of polio, it was only open to British and American audiences. It also launched the U.S. artists program of music as an instrument of reorientation and re-education, a concept that originated in late 1945 and that General Clay initially had resisted, as he felt that the Germans had to achieve this for themselves (see also Monod, 2005, 213). In the first concert Menuhin raised a total of 3,000 U.S. dollars for charity (an amount that would equal 30,000 dollars today), a third of which went for purchasing orthopedic instruments needed due to an ongoing polio epidemic. Further proceeds of the benefit concerts were given to the five Berlin orchestras to buy new instruments (Burton, 2000, 283).

The second concert, conceived as a repeat performance open to the general German public, took place two days later on Tuesday, September 30, 1947, also at the Titania Palast. It was recorded as well. In a letter to the Commanding Officer of the Berlin Command, General Frank L. Howley reports of this concert as being "one of the most important steps thus far undertaken in Berlin by the War Department in connection with the reorientation policy"24. However, it was "marred by a number of incidents for which Military Police [henceforth MP] and Special Services officials were responsible, thus making it appear in the eyes of the Germans that Americans are not sincerely appreciative in cultural activities". Apparently, the audience was allowed to enter in single file, so that all "passes" could be checked; this delayed the start of the concert by over an hour, and "many... prominent Germans", including music critics, "were not permitted to take their seats" (Thacker, 2007, 103). People were still coming in during the first two pieces; "during the playing of the Beethoven [Violin] Concerto MP's walked up and down the aisles asking for passes from Germans and Allies. Persons without passes were ejected. This not only disturbed the audience and Mr. Menuhin but completely nullified the effect the concert was supposed to make"25. And as if Menuhin anticipated the turmoil that was to come, he stated after the performance: "I recognize no races, only people" ${ }^{26}$. The police cleared the hall before anyone could applaud (see also Monod, 2005, 166).
The procedures for the concert ruined its main intention as a successful reorientation event for the German public. They also reveal the ignorance of American officers and their anxiety that it could be remembered as failure to the extent that they arrested lingering pleasure by cutting off applause. The MP's behavior may have been simply ignorance or a desperate attempt at avoiding or controlling any kind of chaos. Or perhaps the officers feared negative reactions, even anti-Semitic actions toward the Jewish violinist from an audience that primarily might have come to hear Furtwängler. But strikingly, Furtwängler's name remained absent from the accounts, letting Menuhin appear as the key figure, who through his postwar performances had the privilege to become the central musician in reorientation performances and also the musical representative for the Jewish people or the Jewish musical representative for the German people.

Menuhin's statement that he recognized no races, only people, can be read in multiple ways. It could have been meant as a response, directed toward the Americans, to how the German audiences were treated before, during, and after the concert, and that they were not quite allowed to listen to the music and enjoy art. In a larger framework, Menuhin's words may be understood as a conciliatory gesture towards the "good" Germans, and his contribution to re-education as he distinguished between "German nationals" and "German individuals". In the end, it may be directed toward himself, as a conscious or subconscious defense of playing with the Nazis' former musical figurehead, Wilhelm Furtwängler. But first and foremost, the statement contradicts the statement that he "might keep alive German guilt".

On October 2, Yehudi Menuhin performed a third charity concert, this time on the invitation of the Russians and together with the Berlin Staatskapelle Orchester under the baton of Wilhelm Furtwängler; all musicians donated their services (Magidoff, 1955, 273) ${ }^{27}$. This concert was also open to the general public, held at the Admiralspalast in the Soviet sector. As the theater held just 1,750 seats, an open dress rehearsal was given before the concert in the evening to enable the two thousand Berlin Jews and victims of fascism, as they were called, to hear the artists perform ${ }^{28}$. The program included Christoph Willibald Gluck's Overture to Alceste, Beethoven's Violin Concerto, and, astonishingly, Richard Wagner's Prelude and "Love-Death" from Tristan 
and Isolde. Menuhin also played Bach's Sonata for Solo Violin in C major. That of all the Berlin concerts the Jewish benefit did not include a piece by a Jewish composer or work forbidden under the Nazis in accordance with current policy is surprising ${ }^{29}$. Perhaps it was a political statement by the Russians, who were in charge of the concert, and had wanted to separate themselves from policies established by the Americans and British; less likely, it was Furtwängler's decision to win artistic autonomy back and to select a program to his liking instead of making politically correct choices. In any event, the program represented a political statement in itself; and it is even more surprising that neither during the dress rehearsal nor during the actual performance did the audience object. Perhaps it was Menuhin's presence that took away attention from the program. Indeed, Walter Hinrichsen, American Music Officer, reported that "there were ovations for half an hour for Mr. Menuhin, and Russian officers and many concert goers agreed that the Staatsoper [sic] had never before witnessed such an outburst of enthusiasm for any artist" (Burton, 2000, 282).

Menuhin's biographer, Robert Magidoff, states that Menuhin only accepted the Berlin performance under the condition that one of the concerts would be for the benefit of the Jewish community of Berlin, and that because of the complexity arranging that concert, it came last in the order of Menuhin's appearances (Magidoff, 1955, 273) ${ }^{30}$. Perhaps the fact that the Soviets organized the event explains the scheduling toward the end of Menuhin's Berlin sojourn (Thacker, 2007, 103). According to Moshe Menuhin, the concert raised about 79,000 marks or 20,000 dollars (an amount that would equal 200,000 dollars today $)^{31}$.

In addition to these three official and public concerts, Menuhin played at a number of other functions, most notably a concert for the DPs in Berlin on October 1, at five o'clock in the afternoon (his fifth day and the only time that had not yet been filled), which proved to be a political challenge rather than an artistic one. Furthermore, this concert was the first point of real contention between the Jewish community, the DPs, and the artists.

Altogether three DP camps existed in Berlin until July 1948: the Mariendorf Bialik-Center and the Düppel Center Schlachtensee in the American zone, and the Wittenau camp in the French zone, with the Düppel Center being by far the largest (in September 1946 it sheltered 5,130 Jewish DPs). These provided a temporary space for mainly Jewish refugees, who could not could and did not want to be repatriated to their original countries and were left homeless as a result of fear of persecution. These Jewish DPs came predominantly from Poland and Russia ${ }^{32}$.

The DPs were very especially offended that Menuhin had played for the Germans and that a good amount of the proceeds went to benefit German institutions. Other than some of the German Jews, they seemed less disturbed by Menuhin's collaboration with Furtwängler ${ }^{33}$. They stirred a controversy and came into the public eye through their boycotting of Menuhin's performance and protesting against the concerts, although their main argument never seemed to be that it was wrong for a Jewish soloist to perform together with a conductor who had been active in the Third Reich, though recently denazified.

In response to the DP protests against Menuhin, Berlin's rabbi Steven Schwarzschild who was on the committee to which the proceeds from the benefit concert in Berlin were turned over ${ }^{34}$, later gave a public testimonial in Menuhin's defense implicating the DPs' prominence in the black market (in fact, the camps were a center of the black market) for instigating these protests as a diversion from their own activities ${ }^{35}$.

The concert on October 1, a Bach recital, took place at the Tivoli, a cinema in the suburb of Berlin-Pankow having a capacity of over four hundred seats. As accounts of the concert and next day's event, Menuhin's visit of the Düppel Center in response to the reception of the October 1 concert, greatly differ, the following two principal perspectives of the events are given separately, the first by Abraham S. Hyman, legal consultant to the American Advisers on Jewish Affairs in Germany between 1946 and 1950, and the other by Yehudi Menuhin, his biographers, and his father Moshe.

Hyman's account is based on oral testimony and reminiscences, most notably interviews with Harold Fishbein and Eliyahu Yones (also known as Jonas of Lemberg) in July 1984 in Tel Aviv, and a recollection of a conversation with Louis E. Levinthal in the later 1940s. The account is somewhat compromised as it relies on the memory of those being interviewed almost 40 years after the events. 
In the case of Eliyahu Yones, a survivor, one might wonder to what extent trauma had an impact on memory -naturally his narrative reflects resentment, anger, and abandonment. In a larger context, the values reflected in the Hyman account, especially the notions of betrayal and despair but also strength and regeneration go hand in hand with the self-identification of the Jewish DPs in the postwar context. Acknowledging their losses and challenges the DPs also recognized their need to develop affirmative responses.

Menuhin's account stems from 1977, written at about the same time Hyman interviewed Fishbein and Yones. As episode of a larger autobiographical narrative, it is also compromised by memory, and thus subjectivity and (unintentional) deception. It is important keep in mind that Menuhin, while focusing on his journey as a violinist, might also have had concerns about his legacy or his status as an American Jew, and that this influenced his telling of the story. The same is valid for his father's account.

Both Hyman and Menuhin are describing the political motivations behind (and preference for) their specific Jewish musical performance, and in both cases music is part of that political expression.

\section{The Accounts}

\section{The Hyman Account}

Contradicting Magidoff, Abraham S. Hyman recalled that Judge Louis E. Levinthal, one of the advisers on Jewish affairs, had suggested to Menuhin that he give a special concert for the DPs, to which Menuhin agreed ${ }^{36}$. Subsequently Harold Fishbein, UNRRA ${ }^{37}$ director of the two main Jewish DP camps in Berlin, at first made arrangements for a concert to be held in Mariendorf. As a large audience was expected, the concert was moved to the Tivoli. In the end, only few DPs attended. To save the situation and avoid embarrassment, Fishbein, gathered about two hundred children from the camps to fill at least part of the hall. After his performance, while still on stage, Menuhin asked Fishbein why people boycotted the program. In a reply, a member of the staff of the Düppel Center camp newspaper, Undzer Lebn: Organ von di befraytn Jidn in Berlin (Our Life: Voice Of the Liberated Jews in Berlin) ${ }^{38}$, handed Menuhin a copy of the paper, which contained an open letter to the violinist written by Eliyahu Yones and an English translation of the letter. Eliyahu Yones was born in Vilnius in 1915 and was trained as a musician and educator. At the outbreak of the Second World War, he fled to Lvov and was incarcerated in several Nazi concentration camps. In August 1943, Yones escaped Kurowice to the forests, where he joined the partisans. After the war, he stayed for a short while in a hospital in Moscow and thereafter in Sochi for rehabilitation. In 1946 he returned to Vilna and from there went to Germany, where he stayed at the the Düppel Center camp. He was founder and editor of Undzer Lebn. ${ }^{39}$

Yones postulated "that if a certain Eppel [sic] were still alive, he would surely attend one of Menuhin's concerts, for when Eppel was S.S. commandant of the slave-labor camp near Lemberg, where Yones was imprisoned for more than two years, he proved his passion for music by having the Jewish children serenade before him before sending them to their death" (Hyman, 1993, 340). Upon reading the letter Menuhin asked to explain himself and with Fishbein's consent he went the following morning to the Düppel Center, this time without his violin, to face a large crowd of Jewish DPs who were both agitated and curious. Menuhin, in an effort of conciliation, justified his Berlin performances by saying that hate is self-destructive and life must go forward; "the people must believe that a new Germany will arise on the ruins of the old and that the German people will live down its embrace of all that Hitler represented" (Hyman, 1993, 341). Although a respondent had not been officially selected, the audience pushed Eliyahu Yones forward, who in Yiddish said "Mr. Menuhin. We the people, and you have no language in common...". The rebuttal was followed by Hatikvah, encouraged by Fishbein. Later, Menuhin apparently changed his views upon visiting the former Reichsbank Frankfurt am Main where Levinthal showed him vaults overflowing with gold jewelry, gold teeth, that the Nazis had removed from the Jews who were deported to concentration camps (Hyman 1993, 342).

Hyman's account gives the impression that there was no reconciliation between the DPs and Menuhin, that opinions and experiences clashed in an unresolvable conflict. The DPs felt they had been robbed, a belief reinforced by 
Menuhin's response ${ }^{40}$. After all, in Jewish law only a victim can forgive, and Menuhin was never directly affected by the Holocaust. Hyman conveys the discord of opinions and emotions by mentioning details pertaining to music. Contradicting Menuhin's account, the Düppel Center meeting took place without Menuhin's violin and instead closed with the DPs' singing of Hatikvah. The Jewish anthem took precedence over Western art music, a clear sign that Jewish collective identity was more important than concert music. In Hyman's account the DPs were proposing an alternative concept of Jewish performance more in line with their perception of postwar Jewish, even Zionist, identity.

\section{Menuhin's Account}

In his autobiography of 1997, Unfinished Journey: Twenty Years Later, Menuhin stood by his defense of Furtwängler and their shared performances, and also shed light on the Düppel Center affair, yet with significant variations and further insights (Menuhin, 1997, 230) ${ }^{41}$. According to Menuhin, the American authorities "obligingly organized a recital", and not at the Düppel Center as Menuhin seemed to have expected. He also estimated that fewer than fifty people were in the audience and did not mention the presence of children; contemporary press reports suggested a few hundred at most ${ }^{42}$. Menuhin recalled his reception the next day at the Düppel Center as initially cold and antagonizing, with boos, hisses, and imprecations. He responded to this accordingly:

I cannot blame anyone for his bitterness... You have suffered too much. And still I do say that you simply cannot rebuild your life on your sufferings. Don't let it be said that we have only learned the worst of our enemies! We Jews don't beg; we work! We are the best cobblers, the best tailors, the best doctors, the best musicians. That's what it means to be a Jew! I have come to Germany to restore that image, to show how false was Hitler's caricature [sic]. That's why I'm here... (1997, 235).

Compared to Hyman's account, Menuhin's recollection is softer in tone and more sympathetic. It also appears to be more elaborate and compelling. But his speech also suggests that he saw his performance as intrinsically linked to politics. The response, according to Menuhin, was "Our Yehudi, our Yehudi", after which he apparently immediately played the violin with no further negative reaction -Menuhin's naïve and overly positive statement might suggest that music here was above and beyond politics, but in the larger context of the events and considering all opinions it is rather reflective of the multiple political attitudes in postwar Germany (and beyond). According to Menuhin, Eliyahu Yones came that evening to apologize to him personally saying that "perhaps it is too much to expect that those who have not experienced persecution and camps should understand our feelings" (Menuhin, 1997, 236) ${ }^{43}$.

Menuhin's diary entry confirms the impression that he first and foremost considered the artistic experience when accepting the invitation to perform in Berlin; he must have been so tempted by the prospect of performing with Furtwängler that he did not think about the consequences: "As I had imagined, to play the greatest German music with this greatest of German conductors was an experience of almost religious intensity. I came down from the clouds to find myself a traitor" (Menuhin, 1997, 234; Burton, 2000, 284). In the end, Menuhin's Berlin concerts with Furtwängler were indeed a significant artistic experience for the young violinist, but tainted by the Düppel Center episode.

With the hope that his experiences in Germany could be of some help in Washington, Menuhin wrote down his impressions, in which he emphasized the "insecurities" plaguing the DPs: "Too long has our government allowed conditions to drift. We should have liquidated the DP camps two years ago quite independently of any other problems or their solutions. This is a human problem, and these victims should have been offered a choice of nationalities in various countries soon after the war" (Magidoff, 1955, 276). It is quite stunning that after having visited the camps and having met with the DPs at the Düppel Center Menuhin speaks of "insecurities" and "victims" -a perception that was quite removed from the self-perception of the DPs.

The Düppel Center, however, seemed to be only one stumbling block in the reception of Menuhin's Berlin concerts. In fact, Menuhin himself stated that "winning the understanding of the wronged men and women of the Deuppel [sic!] Centre proved both more painful and simpler than outfacing the protests of the Jews of America" (Menuhin, 1997, 236). 
If indeed, Yehudi was concerned about his status as an American Jew, his father was even more concerned. On January 12, 1950, he wrote a six-page single-spaced letter to the New York-based Yiddish-language newspaper Der Tog (the Day), in response to Mordechai Danzis's article "Un Menuhin fidelt" (While Menuhin Fiddled) ${ }^{44}$. Danzis lambasted Menuhin for playing with Furtwängler only because the violinist "loves to play with the murderers of his people". Moshe Menuhin's typescript gives his own detailed and angry version of the Berlin affair -Der Tog never printed $\mathrm{it}^{45}$.

Insulting Danzis as a psychopath, he called the article a "smear and whispering campaign against Yehudi" that culminated in "shameless, malicious, and irresponsible defamations". These defamations refer to the following accusations made by Danzis: Menuhin's Berlin postwar performances, his collaboration with Furtwängler, and his defense of the conductor are shameful. In Yehudi's defense, Moshe Menuhin argued that most of his son's Berlin concerts benefited the cause of the Jewish people directly and indirectly. He justified the 1947 Jewish benefit concert in Berlin with the fact that it raised money for the Jewish community and was supported by the local rabbi; he justified his son's collaboration with the presence of Jewish musicians in the orchestra. He used similar arguments to defend Yehudi's benefit concerts in Berlin of fall 1949. Another point made by Moshe is the fact that the U.S. government encouraged and supported Yehudi to play these concerts in Berlin. While this has little to do with the Jewish question and rather confirms that for the government, Menuhin's Berlin concerts were important publicity, it shows that political connotations seemed more important than artistic expression.

In regard to the Furtwängler issue, Moshe claimed that the conductor "was persecuted and haunted by Hitler" and if it would not have been for the quick end of the war, "he would have landed in one of the concentration camps as all other caught liberals and anti-Nazis". Moshe insisted that his son did very serious research on Furtwängler only to come to the conclusion that the conductor was "righteous, liberal, anti-Nazi"; he closed with the somewhat unconvincing phrase that Furtwängler "is a great conductor, probably the greatest in the world. He is German, of course, but one of those Germans who belong to all mankind who cannot be confused with Nazis". Furt- wängler's denazification tribunal and its accusations are not mentioned the least.

Moshe concluded his letter with extensive quotations from the letter his son sent to Washington in fall 1947, upon completing his Europe sojourn. Perhaps nothing is more telling than the following sentence: "I went to Germany as an American at the service of my country and my government after prolonged and urgent requests. Not for one moment did I forget my duties to, my respect and sympathy for my [the Jewish] people. I fully realized, though it was not publicized, that directly and indirectly, I had here an opportunity to serve the cause of the Jewish people". The Menuhins, for sure, saw in the Berlin performances a great artistic opportunity; if they first and foremost had the Jewish people in mind remains doubtful. In the end, it appears that the Menuhins never fully grasp the atrocities of the Holocaust and because of that acted insensitively and in their own interest. Yehudi Menuhin's letter to Washington underlines that in the following incredible sentence: The persecuted Jews "have even reluctantly admitted to me that perhaps it was not quite so great a crime as they had originally supposed or were led to believe".

\section{The Reception}

On October 3, 1947, when Menuhin left Berlin, his concerts and the Düppel Center encounter began to be covered by a variety of newspapers in Germany and overseas. The Jidisze Cajtung: Algemejn-Nacjonaler Organ (Yiddish Newspaper: General National Publication) published a cartoon drawn by fourteen-year-old Shmuel Bak ${ }^{46}$, who lived with his mother in the Landsberg DP camp, in response to the first concert on September 28. The cartoon shows Menuhin playing in front of a group of children who hold a sign with the German line "German Hitler [Hitler is crossed out] Youth"; the caption reads: "Last Sunday Yehudi Menuhin gave a concert in Berlin. The proceeds were given to a German project as shown in the drawing". Evidently, Bak did not know that the proceeds of the first concert were not meant for the German charities, but supported the Allies. The cartoon appeared on the same page as a report about the deconsecrating of Jewish cemeteries on German soil on the eve of Yom Kippur 194747. Apparently, anti-German sentiments for the concerts were reinforced through 
mentioning anti-Semitic behavior, which was indeed still prevalent at the time. In this context, Menuhin's alliance with Furtwängler and the benefit for non-Jewish causes were even more offensive.

The third concert was covered in the weekly paper of the Berlin Jews, Der Weg, of October 10, 1947, in a review by musicologist and critic Ludwig Misch, titled "Yehudi Menuhin and Furtwängler play for the Jews"48. Misch justified the delay in covering the event -not even an announcement was published in Der Weg-due to the tight schedule of the Berlin Philharmonic Orchestra and Menuhin's last minute decision [sic] to do this concert. It was the first event for a Jewish organization in Berlin organized by non-Jews since the end of the Nazi regime. Misch saw the event as an act of Wiedergutmachung ${ }^{49}$. He himself had published an article on February 6, 1946, in Neue Zeit, titled "Ich melde mich als Zeuge: Zum 'Fall Furtwängler'" (I Report as Witness: On the Case of Furtwängler), in which he had insisted that Furtwängler had (passively) opposed the Nazi regime ${ }^{50}$. Misch based his defense largely on information by Paul Schwers, editor of the Allgemeine Musikzeitung, and on his own experiences: In the summer of 1933 and at the end of 1938, Furtwängler had supported Misch in his attempts to emigrate, and also wrote a benevolent letter when Misch was no longer allowed to teach at a Jewish school.

It is important to keep in mind that Misch, an assimilated Jew, was an established music critic, conductor, teacher, and an authority on Beethoven before 1933, and mingled little with the Jewish community. After 1933 this changed as Nazi policy forced him to shift his professional focus from German culture to Jewish culture. He began working in Jewish schools, wrote for the Jewish community paper, took part in Jewish Kulturbund concerts, and renamed his own a cappella choir, Neue Madrigalvereinigung, to Jüdische Madrigalvereinigung. Misch was spared from deportation to a concentration camp because he was married to a Christian. In 1947, he moved to New York City, where he continued writing about the life and work of Beethoven. Misch's stance on German society and his relatively moderate treatment during the Holocaust are very much reflected in his postwar role as defender of Furtwängler.

Misch's criticism extended primarily to the performance itself, not the performers, their motives, and background. He regretted, however, that they did not perform a sym- phony or piece by a Jewish composer and ascribed this to the late decision to offer this concert. Overall, Misch gave the performers and their interpretations much praise, and attested that the audience did the same. Apparently the board of the Jewish community met with the artists after the concert and expressed their gratitude ${ }^{51}$. Misch connected politics very deliberately to the concert by describing it as an act of Wiedergutmachung, a term that was distinctly political in the postwar context. Despite its emphasis on the repertory and quality of the performance, his description is specifically politicized.

Most of the German critics reported on Menuhin's concerts as musical events, divorced from politics. The decision to refrain from overt mention of the war and its aftermath is political in and of itself; it suggests a level of postwar discomfort, cultural amnesia or avoidance, or a distinct political agenda. The composer, musicologist, and music critic Hans Heinz Stuckenschmidt, in his review of the first concert published by Die Neue Zeitung: Eine amerikanische Zeitung für die deutsche Bevölkerung-Berliner Blatt on September 30, 1947, only focused on Menuhin's playing; he was critical that only Americans were allowed into the concert. Karl Schönewolf, later one of the best-known music critics of East Germany, most likely reporting on the second concert, also focused his review on the artistic side of the event. Menuhin apparently played as encore the Partita for solo violin No. 3 in E major by Johann Sebastian $\mathrm{Bach}^{52}$. The controversies surrounding the concerts were not mentioned in the least ${ }^{53}$.

Only the critic of Der Kurier: Die Berliner Abendzeitung alluded to the uniqueness of the concerts by mentioning Menuhin's background in the first paragraph of the review: "Some have wondered that here on Monday Yehudi Menuhin has been called a great Jewish violinist [emphasis in original]. But this happened with deliberation and justification. This born American comes from a Zionist home ${ }^{54}$. That it is he, who came as the first foreign artist of international fame to Germany, to play in front of Germans, that's its own matter. A number of great artists believe that their art is a reward that the German public still has to earn. Menuhin does not share this opinion. He, like Beethoven, sees great and pure art as medicine that can help to recover sick souls. This is a true and also a good Jewish notion, that the strong should support the weak"55. The reviewer went on to praise Yehudi's strength as performer and evaluated 
the performance as being more than "medication" -it was a "revelation". One cannot help but notice the tone of the review, especially in reference to Menuhin's Jewish heritage. It seems as if the critic had difficulty to neutral and to solely look at Menuhin as performer. He was the only critic who pointed toward Menuhin's Jewish identity, but not without a certain discomfort.

While the German press overlooked the Düppel Center incident altogether, the foreign press made it the focus of their reports. Two U.S. reporters who heard of the meeting at the Düppel Center interviewed Yones and on October 27, 1947, just a few weeks after the incident, published a brief article in Time Magazine, titled "Music: Not by Hate", with some substantial excerpts from Yones's letter and Menuhin's response, but again with significant variation that gives the sense of Menuhin's imputation of blame: "I have played for the hard-pressed wherever and whenever I could... You are truly the victims of Nazism, but the tragedy is that you [italics by the author, in the Magidoff account "we" is used] have grown to be like the Nazis... You [ibid.] make your judgments on a racial basis, and you demand that art and music be harnessed in the cause of hate. Love and not hate will heal the world". Contradicting Menuhin's statements, the article states that the DPs remained silent and that Menuhin "left his fiddle at home". A conciliatory reply by Yones reads "If Menuhin offered us a concert today, we would all go. Perhaps it is too much to expect that those who have not experienced persecutions and camps should understand our feelings" ${ }^{16}$.

The Düppel Center affair was also covered by the weekly The Canadian Jewish Chronicle of October 31, 1947, in an article titled "They Required Us of a Song"57, in which Menuhin is criticized not primarily for his actions, but rather his naiveté and insensitivity. Some Jewish newspapers in the United States and many in Israel censured Menuhin for playing with Furtwängler and for performing for German audiences (Magidoff, 1955, 277-278).

But despite the 1947 experience and the fact that the postwar affair remained in the press ${ }^{58}$, the violinist continued to give charity concerts in Germany ${ }^{59}$. U.S. military and civilian authorities in Germany and political advisor Robert Murphy and later High Commissioner John J. McCloy, kept repeatedly and urgently inviting Menuhin back to Germany as America's cultural ambassador and "mis- sionary". The identity of the world-renowned American Jew may have been a strong factor in Menuhin becoming the cultural ambassador.

Menuhin's firm position on Furtwängler and his engagements in Germany led Rome to boycott two of his concerts in January $1949^{60}$. Further debate arose when in the same month Menuhin threatened not to appear with the Chicago Symphony Orchestra until they engaged Furtwängler; in contrast a good number of artists firmly stated that they would refuse to appear under Furtwängler if the Chicago Symphony Orchestra hired him as conductor ${ }^{61}$. In the end, Furtwängler withdrew as a prospective guest conductor ${ }^{62}$.

Later activity in Germany earned him unexpected criticism in the United States leading Menuhin in 1949 to make a statement explaining the necessity of his concert activities $^{63}$. But criticism eventually ceded. In Germany, the Jewish community celebrated a concert given by Yehudi Menuhin on April 10, 1951, in Hamburg as the greatest cultural event (Lamm, 1960, 141).

Only Menuhin's performances in Israel continued to be overshadowed by the past, at least initially. Although he had wanted to visit shortly after the foundation of the state, Israel was almost two years old when Menuhin could finally undertake his first tour there in April 1950 (Menuhin, 1997, 237). Russian impresario Baruch Gillon invited Menuhin, but then discouraged a tour as assassination threats from a terrorist group made Menuhin's appearance a national issue (Magidoff, 1955, 79). Menuhin wired him: "Precisely because I played in Berlin I wish to play in Israel" (Menuhin, 1997, 237). Menuhin seemed to have embraced his status as cultural ambassador and political figure. Upon his arrival he notes "It was the Deuppel [sic!] Centre all over again" (Menuhin, 1997, 237). After Menuhin's first performance the negative sentiments disappeared: "Within a couple of days all precautions had withered away in a climate of unambiguous good will, and my long, sometimes fault-finding, always sympathetic involvement with my fellow men of the State of Israel had begun" (Menuhin, 1997, 237-238). Menuhin played twenty-four recitals in twelve days in different cities and kibbutzim as well as military hospitals.

In 1954, a good seven years after the Menuhin affair and a week after Furtwängler's passing on November 30, 
$1954^{64}$, Ludwig Misch published an article in the New Yorker Staats-Zeitung und Herold, titled "Helfer der Bedrängten: Erinnerungen an Wilhelm Furtwängler" (Helper of the Desperate: Reminiscences on Wilhelm Furtwängler) ${ }^{65}$, in which he described his personal encounter with the conductor and his innocence during the Nazi period. The article was motivated by the fact that Furtwängler still experienced resentment in the United States due to his alleged involvement in Nazi Germany. Misch reiterated information he had already provided in his 1946 article in Neue Zeit, particularly that Furtwängler helped him with supportive letters during the 1930s. He added excerpts from a conversation during which Furtwängler had emphatically stated: "I am myself a prisoner". Misch also mentioned that it was he and his wife who had encouraged Furtwängler to give the benefit concert for the Jewish community in 1947. Furtwängler apparently had countered that he would prefer to be invited by the Jewish community. Indeed, Furtwängler felt that by offering a benefit, he would appear guilty and perhaps would face more allegations. Misch in his final sentence underlined that Furtwängler's humanity was as great as his artistry.

This article triggered a response by Hans-Erich Fabian, a lawyer, who had survived Theresienstadt, returned to Berlin, and became the chairman of the Jewish community there. In a letter to Misch, Fabian commented on this article and particularly Misch's words about the Berlin concert. Fabian criticized Misch's statement on the benefit concert. There had never been communication with the Jewish community about organizing the benefit and thus, Fabian assumed, this concert was just organized to rule out hostile reactions to the Berlin concerts. In fact, the Jewish community only learned about the benefit concert from Litfassäulen (advertising pillars). If the Jewish community had made it known that they had nothing to do with this concert it would have led to a scandal, which had put Fabian in a precarious position as he did not want to compromise the artists. To save the situation and to keep the calm with the DPs, with whom Menuhin already had an unpleasant encounter, Fabian apparently acknowledged the involvement of the Jewish community in the event. On his initiative, the dress rehearsal was specifically for the Jewish senior citizens and victims of fascism, so that the Jewish community would not merely benefit financially. One may wonder why they did not receive seats for the evening performance. In any event, after the evening concert, the board members had to restrain themselves so as not to show their displeasure with the whole affair. Fabian emphasized his convictions that Furtwängler was not a Nazi per se, but that the accusations against him were justified given that he worked in the name of and for the Nazi regime ${ }^{66}$.

In his answer a week later, Misch insisted that he (or rather his wife) had the idea to involve Furtwängler and that it was he who established the contact between the artist and the board of the Jewish community. He quoted as witnesses the writer and journalist Richard May and the editor-in-chief of Der Weg, Wilhelm Maier. Misch also remarked that, albeit his efforts to establish the contact, he was not even invited to the meeting of Furtwängler and the board. Lastly, Furtwängler would not need the "protection" of Fabian and the Jewish community. Misch's disagreement took place on many fronts.

The Holocaust and the ordeals of the camps (both during the Third Reich and after) were certainly a profound event, one that sensitized the DPs in a much deeper way than those who survived the Holocaust in hiding or exile. These divergent experiences and, for that matter, cultures, clashed in the encounter of Menuhin's performances: The DPs (Eliyahu Yones et al.) and camp survivors (Hans-Erich Fabian et al.) naturally took great offense and with it expressed emotional difficulties and struggle, continued suffering, and trauma. Here it is noteworthy that the DPs were the only Jewish faction that seemed to be oblivious to the fact that Menuhin performed with Furtwängler -the conductor was never a central argument in the controversy.

Although the DPs represented a heterogeneous group, given their different countries of origin (the vast majority came from eastern Europe), they united over Menuhin's performances. Indeed, the Düppel Center encounter gives insight into the survivor's understanding of and response to their experience. It showed that they perceived themselves not as passive victims or outcasts, as they showed resistance and tried to raise morale.

Lastly, the Düppel Center encounter exemplifies a trend revealed more broadly in DP life: a complex engagement with the reality that forthrightly acknowledged its despairs and challenges and simultaneously recognized the need to 
develop affirmative responses. It further exemplifies the need for community, strength, and regeneration at this transitional moment and the constructive role fellow Jews, in this respect Menuhin, could have played.

As a musicologist and assimilated German Jew, Ludwig Misch, who survived through mixed marriage, intertwined music and politics in quite different ways. Misch saw in the performance an act of Wiedergutmachung, confirming that his reality during the Holocaust was far apart from the experiences the DPs have had. After all 79,000 marks for the Jewish community, if we believe the amounts Moshe Menuhin had quoted, cannot repair psychological damages and the loss of millions of Jews.

While Furtwängler remained at the margins of the whole affair and, wisely, never got personally involved, Menuhin was one of the central players, who used his identity as American, Jew, and musician to negotiate different places in this political puzzle without compromising his career. Despite the fact that Fabian, Levinthal, Menuhin, and Misch all claimed credit for initiating the benefit concert on October 2, it is clear that in organizing Menuhin's tour the Jewish community and the DPs were, at least initially, on the bottom of his list. This concert particularly seemed more to serve the political than the humane purposes of edification (Erbauung) and recreation or recovery (Erholung) that the Jewish community had explicitly wished for in the aftermath of the Holocaust ${ }^{67}$.

What is striking about the Menuhin affair is the multitude of opinions, experiences, and even "facts" that show how divided Jews in the postwar era were depending on their own unique experiences. The juxtaposition of the exemplary accounts by Hyman and Menuhin reflects the unresolved tension that existed in the Jewish community of Germany and even beyond during a transitional moment in history. The different perspectives account for the complexity and diversity of postwar political expression and they point to plural notions of Jewish identity, values, and experiences but also to its fractures. Thus Menuhin's concerts provided an opportunity to grapple with both the implications of the recent genocide, and some of the major questions of postwar life.

\section{NOTES}

1 Accounts on this differ: Hans Hubert Schönzeler $(1990,109)$ states that Menuhin refused to perform as soloist with the Berlin Philharmonic Orchestra in 1933; Lionel Rolfe $(1978,177)$ gives the year 1934. The New York Times published a lengthy article on this affair, in an issue dated January 5, 1934, p. 10.

2 Anonymous, "Nazi Pleas Spurned by Violin Prodigy", New York Times, January 5, 1934, 10

3 For a detailed account on the radio broadcast of the Mendelssohn Violin Concerto by Major Bornoff of the British Army of Occupation, who was in charge of music for the radio station Norddeutscher Rundfunk (see Bornoff, 1986, 31-33).
4 A remarkable anecdote about their performance can be found in Donald Mitchell and Philip Reed's edition of Britten's correspondence and diaries. In the notes, the editors quote from a letter that Anita Lasker, a young cellist who had survived the camp, wrote to her aunt after the recital: "It was a beautiful evening. Both soloist and accompanist were of a simplicity regarding their attire which almost bordered on the slovenly, which fitted the local atmosphere perfectly. No need to mention that Menuhin played violinistically to perfection... Concerning the accompanist [Britten], I can only say that I just cannot imagine anything more beautiful (wonderful). Somehow one never noticed that here was any accompanying going on at all, and yet I had
Aceptado: 15 de febrero de 2011 
to stare at this man like one transfixed as he sat seemingly suspended between chair and keyboard, playing so beautifully". Britten, 1998, 12731274. Another account of the concert can be found in the memoires of Lilka Trzcinska-Croydon, 2004, 131-134, a political prisoner held at Auschwitz during the Second World War. For a brief survey of other accounts, see Fetthauer, 2009, 374-376.

5 New York Times, December 5, 1945, 26. Menuhin's defense of Furtwängler took place during his Paris sojourn; reporters sent the statements to New York (see Rolfe, 1978, 201).

6 For full-length response, see ibid. For more quotations of Hirschmann's and Menuhin's statements see the anon., "Menuhin Calls on Allied World to Accept Fuertwaengler Again", New York Times, December 5, 1947; anon. "Furtwaengler Storm Center in Music Row", New York Post, December 11, 1945, 5 and 18; and Arnold Blom, "Menuhin 'Horrifies' Hirschmann With His Pleas for Furtwaengler", PM Daily, December 11, 1945, 16. It is noteworthy that in the newspaper coverage Menuhin is presented as an American musician -his Jewish heritage is not emphasized.

7 According to Giles MacDonogh (2007, 336), Furtwängler had sealed his fate with many Jewish Americans when in 1936 he had been offered the position of principal conductor of the New York Philharmonic but chose to direct the orchestra of the Berlin State Opera instead. This statement, however, is not quite true. Furtwängler, in fact, did not turn down the position, but was rejected.

8 At the end of January 1946, Furtwängler went to Vienna, where the Austrian denazification took place. Burton states $(2000,262)$ that the two musicians met for the first time in May 1946 in Zurich at the wedding of Griselda Grould and Louis Kentner.

9 On Furtwängler's own account see Furtwängler, 1989, 155-160.

10 For the insistence in Furtwängler's return to Germany, see also the open letter "Berlin ruft Wilhelm Furtwängler" (Berlin Calls Wilhelm Furtwängler) by leading members of the Philharmonic and the Kulturbund, in the February 16, 1946, edition of the Soviet Sector's Berliner Zeitung 2, no. 39, February 16, 1946, and subsequent articles in the same paper: "All of us who want to build the new democratic Germany in the spirit of humanity need the high symbol of artistic perfection which for us Germans, after the barbaric relapse of National Socialism, is the clarion call to self-knowledge.... Your birthplace appeals to you to return to it". A larger excerpt in English translation can be found in Clare, 1990, 101. For more information on this episode, see Janik, 2005, 136.

11 For a full and excellently documented account see Monod, 2005, 128-155. See also Toby Thacker's (2007, 53-54) assertion that the Furtwängler case served as a symbol. For an eye-witness reports of the British intelligence officer George Clare, see Clare, 1990, 100-115. Curt Riess (1955, 213-226), a refugee from Nazi Germany who returned as an American war correspondent to record the demise of Hitler's Third Reich, in order to lift Furtwängler's ban, describes the events in Austria and Germany and his alleged involvement in the case in his book, Wilhelm Furtwängler: $A$ Biography, claimaining that he was responsible for expediting the German trial. Reprints of contemporary news coverage and documents related to the trials can be found in Höcker, 1968, 90-98.

12 According to Giles MacDonogh (2007, 354-355), the session took place at the Spruchkammer in the Schlüterstrasse in Berlin, which was run by the British mayor Kaye Sely, head of the Information Services Control Intelligence Section. The hearing session lasted five hours.

13 Other detailed accounts can be found in Shirakawa, 1992; Monod, 2005, 128-136, 146-155; Thacker, 2007, 53.

14 Many earlier studies have reported on the events in the context of "conspiracy theories". Literatures that assume Furtwängler's innocence to include Schönzeler, 1990, 106-107; Prieberg, 1991; and Gefen, 2001.

15 Literatures that assume the conductor's guilt include Wessling, 1985; Kater, 1997; Haffner, 2003. For a detailed account on Furtwängler's life between the end of the war and analysis of some of the literature mentioned above, see Smithson, 1997.

16 Samuel Lewis Gaber to Yehudi Menuhin, August 14, 1947, Leo Schwartz Papers at YIVO Institute for Jewish Research, MK 488, reel 35, folder 421.

17 Anonymous, "Ein Leben für die Geige", Der Spiegel 35, August 30, 1947, 17.

18 Kathleen McLaughlin, "Germans Absolve Dr. Furtwaengler", New York Times, April 20, 1947, 20.

19 Anon., "Ruling on Furtwaengler", New York Times, May 15, 1947, 32.

20 lbid.

21 Beside the three concerts, Menuhin played solo violin during the screening of the English film Paganini at the Marmorhaus cinema, see anon. 
"Yehudi Menuhin", Der Morgen 3, no. 225, September 26, 1947, 2. In accordance with Menuhin's wishes, the proceeds of this performance went to the Hochschule für Musik and the Internationales Musikinstitut in Zehlendorf.

22 In a good number of literatures, the dates and subsequent events of the three concerts have been confused or misstated. My dating is based on various newspaper reports and Hunt and Schönzeler, 1990.

23 According to Toby Thacker (2007, 76 and 90), after the war almost all German orchestras started a concert with a Mendelssohn piece to conform to the American enforcement of performing at least one piece by a composer forbidden under the $\mathrm{Na-}$ zis.

24 Letter from Frank. L. Howley to Commanding Officer, Berlin Command, October 1, 1947 (held at the Institut für Zeitgeschichte, Munich, Office of Military Government United States, 5/267-3/4), quoted after Thacker, 2007, 103.

25 Letter from Frank. L. Howley to Commanding Officer, Berlin Command, October 1, 1947, quoted after Thacker, Music after Hitler, 103-104. For further details on the concert see anonymous, "Tumult um die Karten: Menuhin, Berliner und ein MP-Mann", Der Spiegel 40, October 4, 1947, 19.

26 Anon., "Yehudi Menuhin Plays in Berlin", New York Times, October 1, 1947, 35.

27 According to David Monod (2005, 211), the Germans supported by the Military Government paid Menuhin on the understanding that he would then donate his honorarium back to the Berlin Philharmonic Orchestra. Whether this also applied to the
September performances is unclear. Menuhin had already performed in September 1946 in Berlin with the Berlin Philharmonic Orchestra before the Allied troops.

28 Ludwig Misch, "Yehudi Menuhin und Furtwängler spielen für die Juden", Der Weg 2, no. 41, October 10, 1947, 5.

29 See footnote no. 23.

30 Magidoff and Humphrey Burton also claim that the concert was held at the State Opera House in the Russian Zone, however, as the house Unter den Linden was largely destroyed, the Staatskapelle used the Admiralspalast until 1955.

31 Moshe Menuhin, typescript copy, January 12, 1950, private collection of Schwarzschild family.

32 For a detailed history see Königseder, 1998.

33 Later that year in Vienna, 150 former concentration camp inmates protested against Furtwängler's performance and some of his entourage were injured; see "Kulturnotizen", Neue Welt: Mitteilungsblatt der jüdischen Gemeinden in Bayern 1, no. 5 (1947), 10.

34 Schwarzschild was born in Frankfurt am Main and grew up in Berlin. He emigrated to the United States in 1939 and was ordained at Hebrew Union College in Cincinnati in 1948. He served as chief rabbi of the Berlin Jewish Community from 1948 to 1950 under the auspices of the World Union for Progressive Judaism. His arrival many months after the actual affair, yet his involvement suggests that the scandal continued to simmer in various ways: for one, the Community Board which received the proceeds from Menuhin's benefit concert might not actually have received the money, or might certainly not have considered what to do with the money, until after Schwarzschild arrived and joined the Board.

35 Interview and correspondence with Maimon Schwarzschild, New York/ San Diego, May 2010. No written account of the testimonial could be found. However, in 1949 similar protests arose against the British film Oliver Twist of 1948 and Schwarzschild took the same stance.

36 According to Magidoff $(1955,273)$, it was Menuhin himself who offered to play this recital.

37 United Nations Relief and Rehabilitation Administration (UNRRA) assisted in the repatriation of millions of refugees in 1945 and managed hundreds of DP camps in Germany, Italy, and Austria.

38 The Yiddish-language paper was published in irregular intervals from August 2, 1946, until 1948. The print run was between 2,000 and 3,000 copies; see Königseder, 2001, 41.

39 Yones immigrated to Israel in 1950 and worked for the Israeli Broadcasting Authority. At the age of 79, he received his doctorate in Jewish history from the Hebrew University in Jerusalem. He was a board member at Yad Vashem since the museum's establishment. He still lives in Jerusalem.

40 Different versions of the response are cited below.

41 The first edition of this autobiography contains the exact same account, see Menuhin, 1997, 223-229. See also Menuhin, 1986, 51-60.

42 Time Magazine speaks of 600 [sic] people in the audience; see "Music: Not by Hate", Time Magazine, October 27, 1947; www.time.com/time/ magazine/article/0,9171,854834,00. html (March 22, 2010), Lionel Rolfe $(1978,2000)$ mentions only 15. 
43 Magidoff quotes the speech at even greater length: "I've come to speak to you as a Jew, and to tell you that what l've done, I've done as a Jew... There are many ways of a person to behave, and I have behaved in the only way I thought I should, the only way I could. When the Germans allowed Hitler to come to power, I refused to play for them. When they were defeated, my first thoughts were of my own people, and I went to death camps with my violin. We cannot and we must not forget the past, but a time has to come to face the future and to begin building it... To behave toward the Germans the way the Nazis behaved toward us is to admit that we have grown to be like Nazis. Our only way of proving the birthright and greatness of our race is by asserting its strength and virtues and not by imitating evil. We cannot build our future on hatred. We cannot put an end to war and persecution by acts of revenge... I cannot blame anyone for his bitterness... You have suffered too much, you have lost parents, children, brothers, and sisters. I have been spared this torture. And still, I do say that you simply cannot rebuild your life on your suffering. You cannot build your future as victims, you can build it as tailors, doctors, shoemakers, musicians, farmers. Your future is in hard, honest work, just as it is mine and that of all living people. I cannot change myself. I am what my music, my country, and my race have made me, and I can only act as I feel and think is right. You may not agree with me, but you must believe in me and not think of me as a traitor to my people" (1955, 274-275). The speech is also published in Rolfe, 1978. Although it significantly differs from the one transcribed by Magidoff, the essence is the same.

44 Mordechai Danzis, "Un Menuhin fidelt", Der Tog, December 6, 1947, 4.

45 One typescript copy is in the private collection of the Schwarzschild family, with a note in Steven Schwarzschild's handwriting "L'affaire Furtwangler".

46 Samuel Bak was born in 1933 in Vilnius, and was recognized from an early age as possessing extraordinary artistic talent. He and his mother survived the Holocaust in hiding. Before emigrating to Israel in 1948 they lived in different DP camps in Germany. Bak continued his career as an artist; he currently resides in the United States.

47 Jidisze Cajtung:Algemejn-Nacjonaler Organ 73, no. 141, October 3, 1947, 6 . The cartoon is reprinted in Gay, 2002, 197.

48 Ludwig Misch, "Yehudi Menuhin und Furtwängler spielen für die Juden", Der Weg 2, no. 41, October 10, 1947, 5. The Jüdisches Gemeindeblatt für die Britische Zone (now known as the Jüdische Allgemeine Zeitung) did not report on the Menuhin concerts.

49 Generally the German term Wiedergutmachung after the Second World War refers to the reparations that the German government agreed to pay to the direct survivors of the Holocaust, and to those who were made to work as forced labor or who otherwise became victims of the Nazis.

50 Ludwig Misch, "Ich melde mich als Zeuge: Zum 'Fall Furtwängler'", Neue Zeit, February, 6, 1946, 22.

51 Misch, "Yehudi Menuhin und Furtwängler", 5. Burton $(2000,282)$ reports that after the concert the Russians hosted a dinner at an artist club in the Eastern Zone.

52 Karl Schönewolf, "Akkord vollkommener Schönheit: Menuhin, Furt- wängler und Beethoven", Neue Zeit, Ocober 2, 1947.

53 For further reviews, see Hans Heinz Stuckenschmidt, "Vollendetes Musizieren: Yehudi Menuhin und Wilhelm Furtwängler spielen für Berliner Orchester", Die Neue Zeitung: Eine amerikanische Zeitung für die deutsche Bevölkerung-Berliner Blatt 3, no. 78, September 30, 1947, 3; H.E., "Vollendetes Musizieren: Yehudi Menuhin und Wilhelm Furtwängler", Der Morgen 3, no. 230, October 2, 1947, 2; Lothar Band, "Der Geiger Menuhin", Neue Zeit: Tageszeitung der christlich-demokratischen Untion Deutschlands 3, no. 230, October 2, 1947, 2; Erwin Kroll, "Furtwängler und Menuhin", Der Tagesspiegel 3, no. 230, October 2, 1947, 4.

54 To the contrary, Yehudi's father publicly denounced Zionism in 1937. While Moshe had extreme and contradictory positions on issues concerning Jews and the Holocaust, the family remained connected to Judaism, see Rolfe, 1978, 194-195 and 202.

55 R.T., "Arznei und Offenbarung", Der Kurier: Die Berliner Abendzeitung, October 1, 1947. The author of this article could not be identified; neither the imprint of the journal nor the reference books Walther G. Oschilewski (1975): Zeitungen in Berlin, Berlin: Haude \& Spener; and Bruno Jahr (2005): Die deutschsprachige Presse: ein biographisch-bibliographisches Handbuch, Munich, Saur, 2005, list a journalist with the initials R.T.

56 Anon., "Music: Not by Hate", Time Magazine, October 27, 1947; www. time.com/time/magazine/article/0,9171,854834,00.html (accessed March 22, 2010).

57 Anon., "They Required Us of a Song", The Canadian Jewish Chronicle, October 31, 1947, 3. 
58 In 1949, Der Weg reports on four concerts in Berlin, one of them for the benefit of the Jewish community and music (educational) institutions, anon., "Meistergeiger Jehudi Menuhin", Der Weg 4, no. 40, October 7, 1949, 7; see also "M'Cloy [McCloy] Hears Menuhin", New York Times, September 25, 1949, 95. Der Weg also announces Menuhin's first concerts in Israel; see Der Weg 5, no. 5, February 3, 1950, 6. An article from May 1950 mentions attacks against Menuhin for playing in 1947 Berlin and states that Menuhin has regrets to have played these concerts, $Z r_{\text {., }}$ "Jehudi Menuhins Rückkehr," Der Weg 5, no. 20, May 19, 1950, 4. A month later, a "neutral" review of Furtwängler's concert was published that did not convey any animosities against the conductor. H.S. [Hans Stuckenschmidt?], "Furtwängler und die Philharmonie", Der Weg 5, no. 26, June 30, 1950, 4.

59 Menuhin gave another concert in Berlin on June 20,1948, during the embargo and on the day of the German currency reform; however, this time under the baton of Leopold Ludwig as Furtwängler refused to perform due to the circumstances the embargo caused, see Lang, 1988, 110-112. For later concerts with Menuhin see pp. 165 and 169.

60 "Threaten to Boycott Menuhin", New York Times, January 21, 1949, 24.

61 The protests of American musicians extended to Walter Gieseking, "Pianists Warn They'll Boycott Furtwaengler", New York Times, January 6, 1949, 25. For Menuhin's response see "Menuhin Defends Furtwaengler, Asks Chicago to Fulfill Contract", New York Times, January 21, 1949, 25; and "Yehudi Menuhin Raps Critics of Furt- waengler", New York Times, January 23, 1949, 25. For the opposition's view, especially Rabbi Morton M. Berman, see "Rabbi Berman Joins Fight on Furtwaengler", New York Times, January 14, 1949, 12.

62 According to Fred K. Prieberg (1991, 6-8), Furtwängler received anonymous threats before the planned performance in Chicago.

63 See "Menuhin Gives Stand on German Concerts", New York Times, September 27, 1949, 47.

64 Another noteworthy article from that time, published in German for Jewish émigrés in New York, is Artur Holde, "Wilhelm Furtwänglers Tod: Abschluss eines Kapitels deutscher Musikgeschichte", Der Aufbau, December 10, 1954, 5-6, mentioning that the conductor's death destroyed any possibility that he would conduct the Berlin Philharmonic Orchestra during the U.S. tour. Holde stated known and proven facts on Furtwängler during the Third Reich and called him the greatest German musician.

65 Ludwig Misch, "Helfer der Bedrängten: Erinnerungen an Wilhelm Furtwängler", New Yorker Staats-Zeitung und Herold, December 8, 1954.

66 Hans Erich Fabian to Ludwig Misch, December 10, 1954, Leo Baeck Institute, Ludwig Misch Collection, AR 2073.

67 See Georg Glückstein, "Kulturelles Leben", Der Weg: Zeitschrift für Fragen des Judentums 1, no. 2 (1946), 1.

\section{BIBLIOGRAPHY}

Bornoff, Jack (1986): "Yehudi Menuhin: Bridge Builder through Music", in Karl Wilhelm Pohl and Angela ZipfPohl (ed.), Hommage à Yehudi Menuhin: Festschrift zum 70. Geburtstag am
22. April 1986, Baden-Baden, Nomos, 31-33.

Britten, Benjamin (1998): Letters from a Life: The Selected Letters and Diaries of Benjamin Britten, 1913-1976, edited by Donald Mitchell and Philip Reed, 2 vols. Berkeley, University of California Press.

Burton, Humphrey (2000): Menuhin: A Life, London, Faber \& Faber.

Clare, Georg (1990): Before the Wall: Berlin Days, 1946-1948, New York, E.P. Dutton.

Fetthauer, Sophie (2009): "Musik im DPCamp Bergen Belsen", in Beatrix Borchard and Heidy Zimmermann (ed.), Musikwelten-Lebenswelten: Jüdische Identitätssuche in der deutschen $\mathrm{Mu}$ sikkultur, Cologne, Böhlau, 365-379.

Furtwängler, Wilhelm (1989): Notebooks, 1924-1954, edited by Michael Tanner, London, Quartet Books.

Gay, Ruth (2002): Safe among the Germans: Liberated Jews after World War II, New Haven, Yale University Press.

Gefen, Gérard (2001): Wilhelm Furtwängler: La puissance et la gloire, $\mathrm{Pa}-$ ris, L'Archipel.

Haffner, Herbert (2003): Furtwängler, Berlin, Parthas.

Höcker, Karla (ed.) (1968): Wilhelm Furtwängler: Dokumente, Berichte und Bilder, Aufzeichnungen, Berlin, Rembrandt Verlag.

Hunt, John, and Hans Hubert Schönzeler (1990): The Furtwängler Sound: Composer Discography, Chronological Discography, 1926-1954, Concert and Opera Listing, 1906-1954, 3rd ed., Exeter, Wilhelm Furtwängler Society UK.

Hyman, Abraham S. (1993): The Undefeated, Jerusalem, Gefen Publishing House.

Kater, Michael (1997): The Twisted Muse: Musicians and their Music in the Third Reich, New York, Oxford University Press. 
Königseder, Angelika (1998): Flucht nach Berlin: Jüdische Displaced Persons 1945-1948, Dokumente, Texte, Materialien 27, Berlin, Metropol Verlag.

Königseder, Angelika (2001): "Jüdische Displaced Persons in Berlin", in Julius H. Schoeps (ed.), Leben im Land der Täter: Juden im Nachkriegsdeutschland (1945-1952), Sifria 4, Berlin, Jüdische Verlagsanstalt, 33-45.

Janik, Elizabeth (2005): Recomposing German Music: Politics and Musical Tradition in Cold War Berlin, Studies in Central European Histories 40, Leiden, Brill.

Lamm, Hans (1960): "Der Wiederaufbau der Hamburger Jüdischen Gemeinde nach 1945", in Oskar Wolfsberg (ed.), Die Drei-Gemeinde: Aus der Geschichte der jüdischen Gemeinde Altona, Hamburg, Wandsbek, 134-146.

Lang, Klaus (1988): Lieber Herr Celibidache: Wilhelm Furtwängler und sein Statthalter: Ein philharmonischer Konflikt in der Berliner Nachkriegszeit, Zurich, M \& T Verlag.

MacDonogh, Giles (2007): After the Reich: The Brutal History of the Allied Occupation, New York, Basic Books.
Magidoff, Robert (1955): Yehudi Menuhin: The Story of the Man and the Musician, Garden City, NY, Doubleday.

Menuhin, Yehudi (1977): Unfinished Journey, New York, Alfred A. Knopf.

Menuhin, Yehudi (1986): "Furtwängler, Berlin 1947", in Karl Wilhelm Pohl and Angela Zipf-Pohl (ed.), Hommage à Yehudi Menuhin: Festschrift zum 70. Geburtstag am 22. April 1986, BadenBaden, Nomos, 51-60.

Menuhin, Yehudi (1997): Unfinished Journey: Twenty Years Later, New York, Fromm International.

Monod, David (2005): Settling Scores: German Music, Denazification, and the Americans, 1945-1953, Chapel Hill, The University of North Carolina Press.

Pohl, Dieter (1997): Nationalsozialistische Judenverfolgung in Ostgalizien 19411944: Organisation und Durchführung eines staatlichen Massenverbrechens, Munich, Oldenbourg.

Prieberg, Fred K. (1991): Trial of Strength: Wilhelm Furtwängler and the Third Reich, London, Quartet.

Riess, Kurt (1955): Wilhelm Furtwängler: A Biography, London, Muller.
Rolfe, Lionel (1978): The Menuhins: A Family Odyssey, San Francisco, Panjandrum/Aris.

Sanders, Alan (ed.) (1998): Walter Legge: Words and Music, New York: Routledge.

Schönzeler, Hans Hubert (1990): Furtwängler, Portland, OR, Amadeus Press.

Shirakawa, Sam H. (1992): The Devil's Music Master: The Controversial Life and Career of Wilhelm Furtwängler, New York: Oxford University Press.

Smithson, Roger (1997): "Furtwängler's Silent Years, 1945-47"; http://www. furtwangler.net/doc/45-47en.rtf (accessed 22 December 2010).

Thacker, Toby (2007): Music after Hitler, 1945-1955, Aldershot, Ashgate.

Trzcinska-Croydon, Lilka (2004): The Labyrinth of Dangerous Hours: A Memoir of the Second World War, Toronto, University of Toronto Press.

Wessling, Berndt Wilhelm (1985): Furtwängler: Eine kritische Biographie, Stuttgart, Deutsche Verlags-Anstalt.

Yones, Eliyahu (1999): Die Straße nach Lemberg: Zwangsarbeit und Widerstand in Ostgalizien 1941-1944, Geschichte Fischer, Frankfurt am Main, Fischer Taschenbuch Verlag. 